\title{
PERANCANGAN AUGMENTED REALITY UNTUK PETA TOPOGRAFI
}

\author{
Agustinna Yosanny; Muhammad Ismail; Handoko Said \\ Computer Science Department, School of Computer Science, Binus University \\ Jl. K.H. Syahdan No. 9, Palmerah, Jakarta Barat 11480 \\ ayosanny@binus.edu
}

\begin{abstract}
Topography is the science about the earth's surface and other objects such as planets, satellites, and asteroids. Topography is studied at school and is found quite difficult to understand because it requires imagination to understand the meaning of contour maps as well as the lines. To motivate students in learning topography,we design an learning application of interactive topographic map with $3 D$ features using Augmented reality technology. In this research we implement analysis and design method. The result achieved is a learning topographic map application based on augmented reality. The conclusion that can be drawn is the teaching and learning of topography can be more interesting with $3 D$ features so that students can more easily recognize the meaning of contour lines in a topographic map.
\end{abstract}

Keywords: topography, learning, augmented reality, topographic map, 3D

\begin{abstract}
ABSTRAK
Topografi adalah bidang ilmu pengetahuan tentang permukaan bumi dan objek lain seperti planet, satelit, dan asteroid. Topografi dipelajari di sekolah dan cukup sulit dipahami karena membutuhkan imajinasi untuk mengerti arti peta kontur dan garis peta kontur yang ada. Untuk membangkitkan motivasi siswa mempelajari topografi, dirancang sebuah aplikasi pengenalan peta topografi interaktif dengan fitur $3 D$ menggunakan teknologi Augmented reality. Metode peneltian yang digunakan adalah metode analisis dan metode perancangan. Hasil yang dicapai adalah sebuah aplikasi pengenalan peta topografi yang berbasis augmented reality. Kesimpulan yang dapat diambil adalah kegiatan belajar mengajar dapat menjadi lebih menarik dengan adanya fitur 3D sehingga siswa dapat lebih mudah mengenali arti garis kontur dalam peta topografi.
\end{abstract}

Kata kunci: topografi, pembelajaran, augmented reality, peta topografi, 3D. 


\section{PENDAHULUAN}

Salah satu pelajaran di Sekolah Menengah Pertama (SMP) yang sulit dipelajari oleh banyak siswa adalah mata pelajaran Geografi khususnya dalam subbab yang berjudul Topografi. Topografi adalah bidang ilmu pengetahuan tentang permukaan bumi dan objek lain seperti planet, satelit, dan asteroid. Objek geografi terdiri dari bentang budaya dan alam. Bentang budaya adalah semua objek buatan manusia seperti jalan, rel kereta api, pemukiman penduduk, daerah pertanian, dan sebagainya. Sedangkan bentang alam adalah segala sesuatu yang bukan buatan manusia tetapi terbentuk secara alamiah, seperti dataran rendah dan tinggi, gunung, sungai, danau, iklim, jenis tanah (Ginting, 2007).

Siswa sulit mempelajari topografi karena cenderung membutuhkan imajinasi untuk dapat mengerti arti dari sebuah peta kontur itu sendiri dan penjelasan mengenai arti dari setiap garis peta kontur yang ada. Menurut Department of Education and Early Childhood Development, kontur adalah suatu garis yang digambarkan diatas bidang datar melalui titik -titik yang mempunyai ketinggian sama terhadap suatu bidang referensi tertentu. Garis ini merupakan tempat kedudukan titik-titik yang mempunyai ketinggian sama terhadap suatu bidang referensi atau garis khayal yang menghubungkan titik - titik yang mempunyai ketinggian yang sama. Penarikan garis kontur bertujuan untuk memberikan informasi relief (baik secara relative maupun absolute).

Augmented reality merupakan suatu teknologi yang membuat sebuah objek yang diidentifikasi dalam kamera dapat menampilkan bentuk atau animasi 3D yang telah dibuat sebelumnya dengan mengikuti identfikasi dan sususan tertentu. Augmented reality ini masih dalam tahap pengembangan agar dapat dipakai secara luas, namun diperkirakan penggunaannya di masa depan kelak akan sangat banyak sekali manfaatnya bagi masyarakat nanti. Augmented reality sebagai penggabungan bendabenda nyata dan maya di lingkungan nyata secara interaktif dan berjalan langsung dan terdapat integrasi antar benda dalam tiga dimensi, yaitu benda maya terintegrasi dalam dunia nyata (Azuma, 1997).

Berdasarkan masalah yang ada dalam pembelajaran tersebut, dirancanglah sebuah aplikasi pengenalan peta topografi yang dibuat dengan menggunakan teknologi Augmented reality dengan tujuan untuk membantu siswa dalam mempelajari peta kontur pada topografi dan dapat menjadi daya tarik lebih bagi siswa lainnya yang belum mempelajari topografi ini.

\section{METODE}

Metode penelitian yang digunakan dalam penelitian ini adalah analisis dan perancangan. Pada metode analisis, dilakukan pengumpulan data untuk mengetahui tingkat kebutuhan pengguna terhadap aplikasi ini dan fitur-fitur apa saja yang diperlukan di dalam aplikasi. Selain itu juga dilakukan studi pustaka untuk mencari sumber-sumber ilmiah yang dapat mendukung penelitian ini. Setelah data terkumpul, dilakukan analisis terhadap data tersebut yang kemudian dilanjutkan ke tahap perancangan. Dalam metode perancangan, dilakukan beberapa tahapan berdasarkan metode Waterfall. Perancangan meliputi perancangan aplikasi, storyboard dan sistem. Kemudian dilanjutkan dengan implementasi dan evaluasi terhadap sistem yang dibuat.

Berikut adalah use case diagram (Gambar 1) dan arsiterktur perancangan (Gambar 2). 


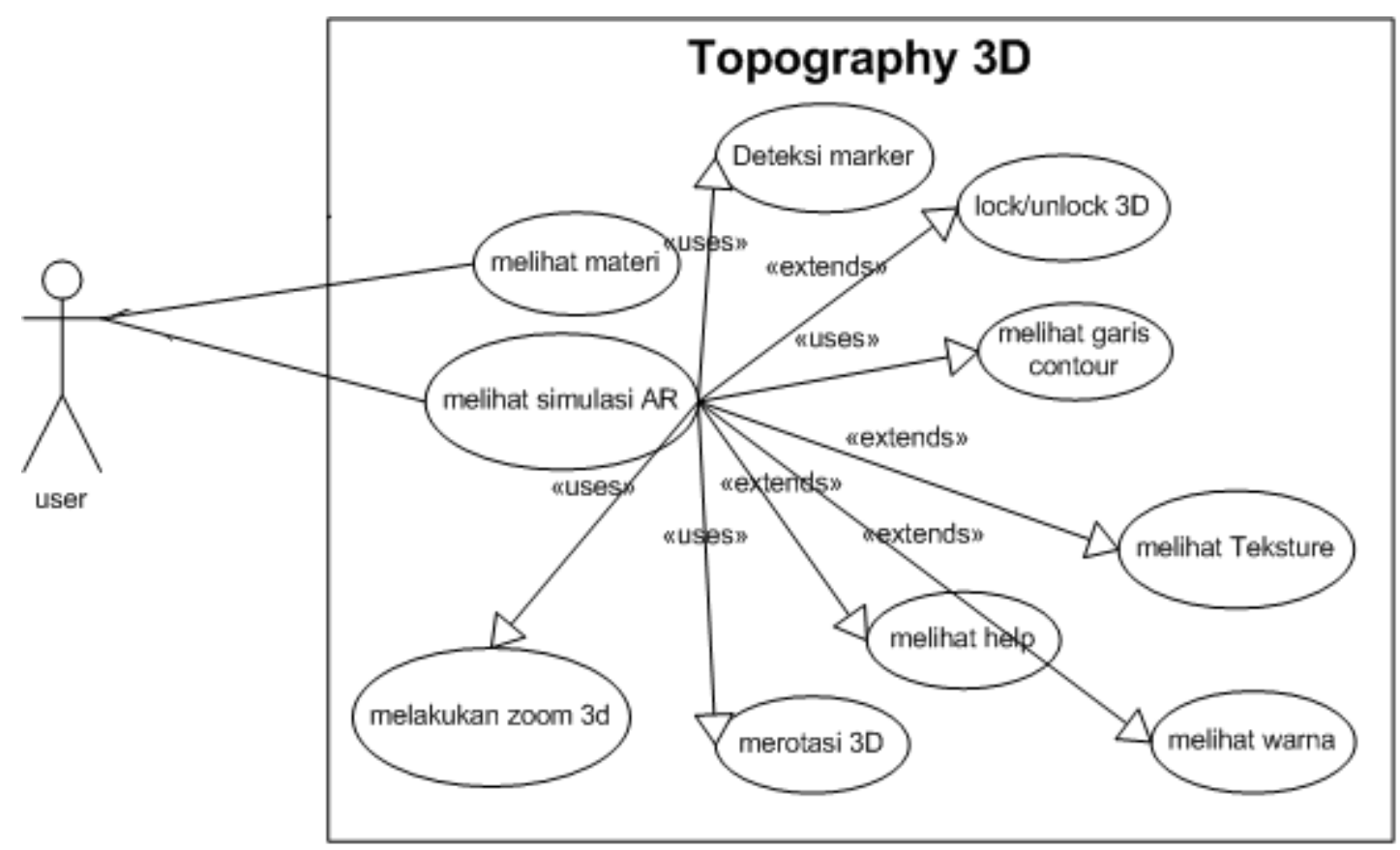

Gambar 1 Use case diagram

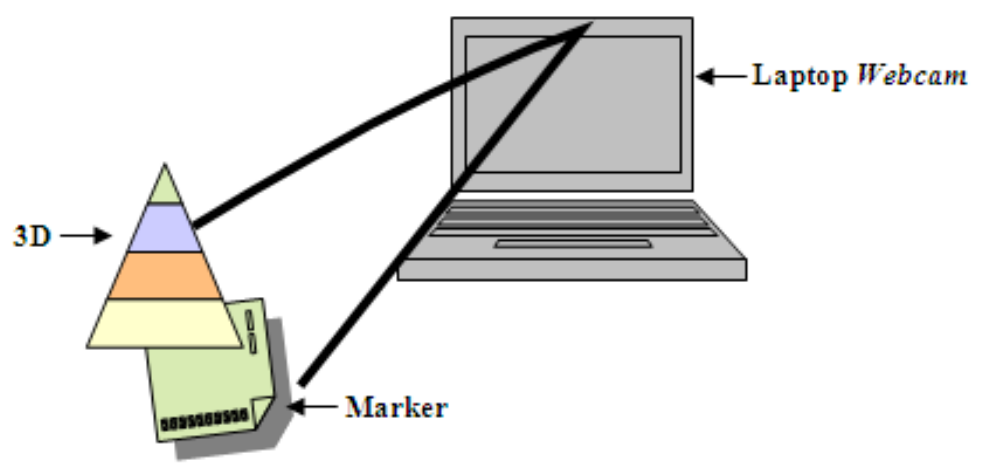

Gambar 2 Arsitektur perancangan

\section{HASIL DAN PEMBAHASAN}

Topografi merupakan salah satu bidang ilmu yang perlu dipelajari. Namun dalam proses pembelajaran, masih banyak kesulitan yang timbul, seperti sulit menafsirkan gambar yang ada dalam peta topografi sehingga materi tidak dapat disampaikan dengan baik. Oleh karena itu, timbullah suatu gagasan untuk membuat suatu aplikasi pembelajaran dengan menggunakan teknologi augmented reality dan fitur 3D sehingga memudahkan siswa dalam memahami dan guru dalam menjelaskan.

\section{Implementasi Aplikasi}

Pada saat aplikasi dijalankan pertama kali, akan ditampilkan layar awal (Gambar 3) yang memiliki tombol Start. Untuk mulai menggunakan aplikasi, user cukup menekan tombol Start yang ada di layar. 


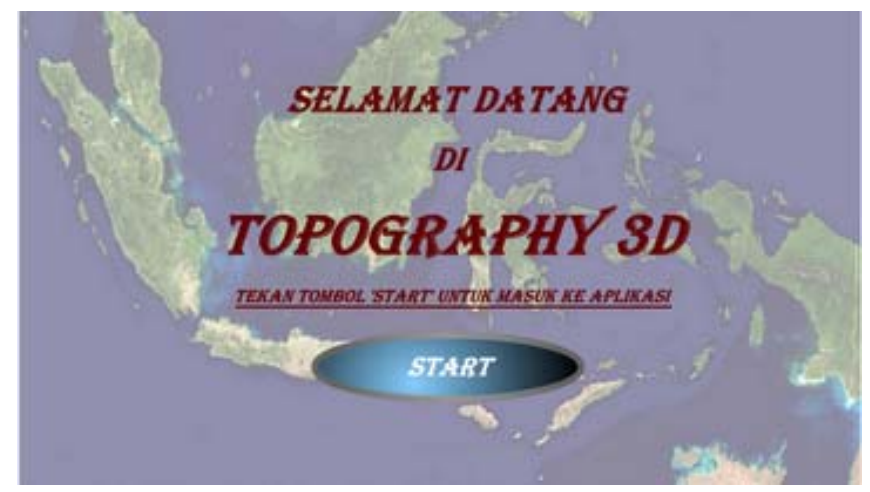

Gambar 3 Tampilan layar menu utama

Selanjutnya ditampilkan menu utama yang terdiri dari 3 submenu, yaitu Materi dan AR, dan Credits (Gambar 4).

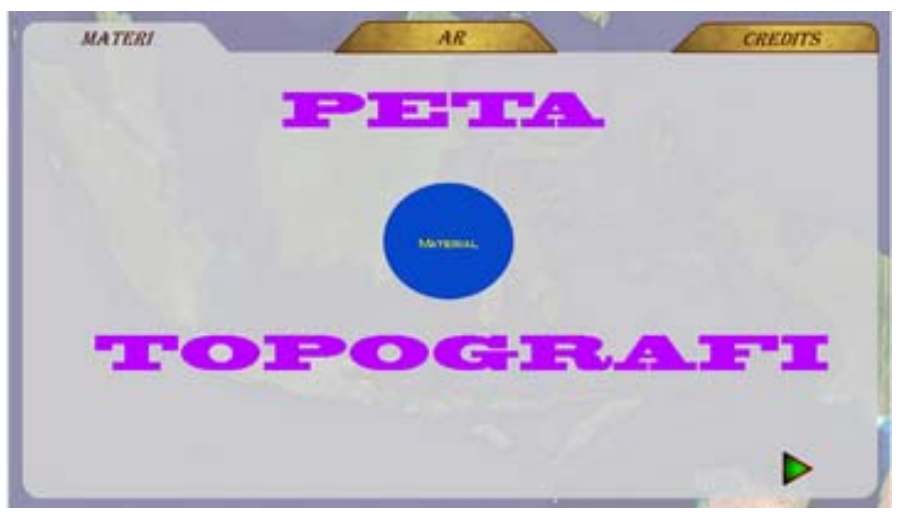

Gambar 4 Tampilan awal layar Materi

Pada layar Materi (Gambar 5), siswa dapat memperoleh penjelasan materi dari peta topografi yang diambil dari salah satu buku teks yang biasa digunakan di sekolah-sekolah. Pengguna dapat menekan tombol panah ke kiri dan kanan untuk mengatur materi yang ingin dilihat.

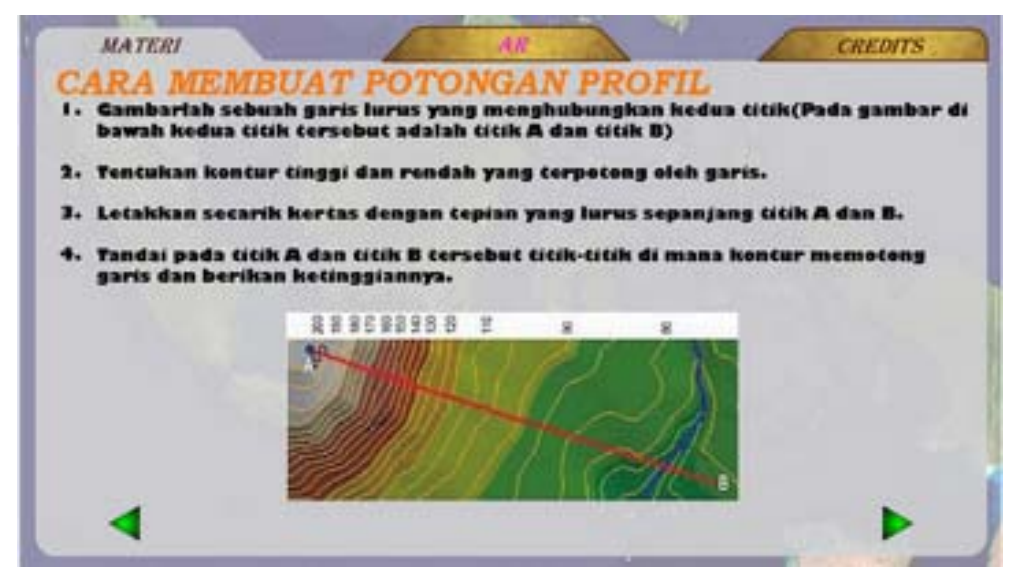

Gambar 5 Tampilan lanjutan layar Materi 
Kemudian submenu AR digunakan untuk mengaktifkan fitur AR sebagai simulasi, supaya pengguna dapat lebih mengerti akan materi. Cara penggunaanya, mula-mula akan user perlu mengarahkan marker ke webcam kemudian user dapat melihat informasi 3D yang diinginkan dengan mengklik 3D yang tampil. User juga dapat membuat 3D yang telah diklik sebelumnya tetap tampil di tengah layar tanpa mengarahkan marker dengan menekan tombol gembok dan begitu pula sebaliknya untuk menghilangkannya.

Fitur AR memiliki beberapa fungsi dengan adanya tombol Color, Contour Lines, Texture untuk mengeluarkan 3D sesuai dengan tombol yang ditekan. Adanya tombol HELP untuk menjelaskan cara memakai aplikasi. Adanya penunjuk informasi 3D mulai dari nama gunung, tinggi skala, dan lokasi gunung berada berikut dengan gambar peta topografi 2D nya (Gambar 6).

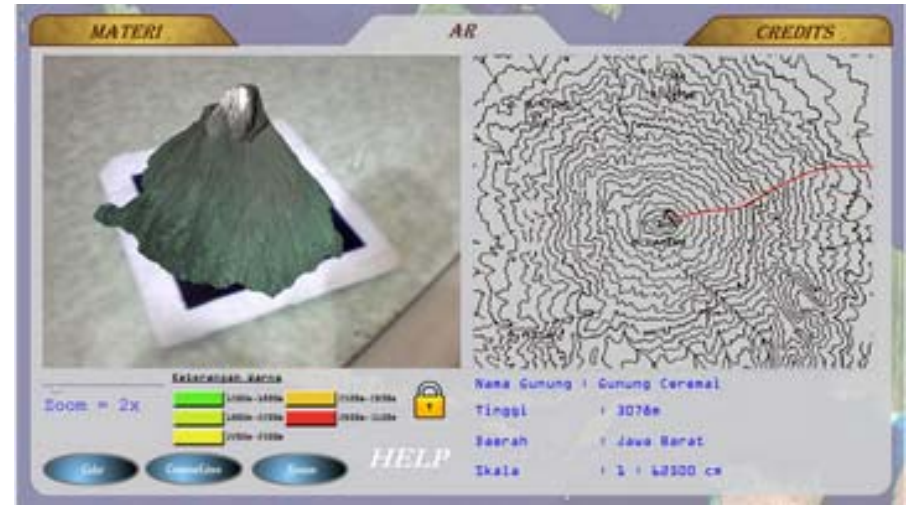

Gambar 6 Tampilan Layar AR

Help (Gambar 7) berfungsi untuk menunjukkan fungsi-fungsi yang ada pada halaman AR berikut cara penggunaannya seperti mengklik 3D untuk memberikan rotasi dan mengeluarkan informasi gunung dan juga tombol lock.

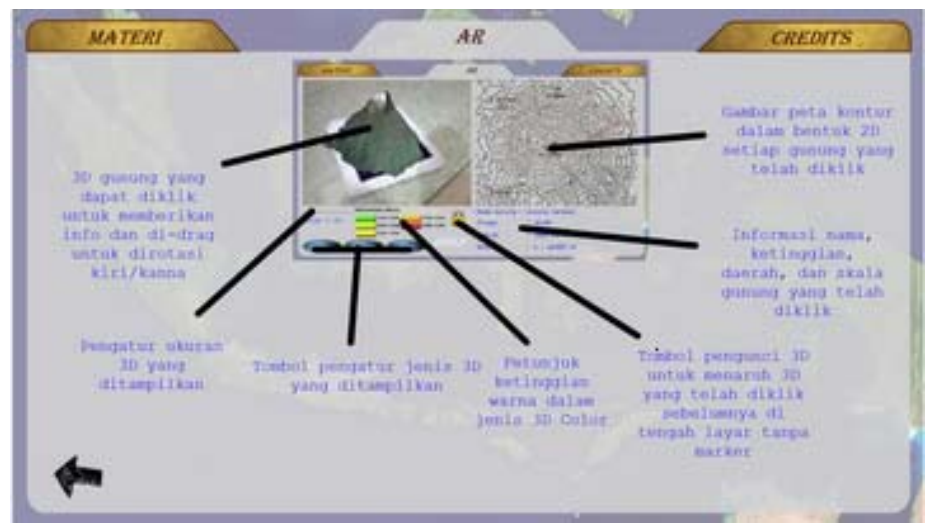

Gambar 7 Tampilan layar Help

\section{PENUTUP}

Berdasarkan analisis, perancangan, implementasi, dan evaluasi aplikasi peta topografi dengan teknologi AR, dapat ditarik beberapa kesimpulan sebagai berikut. Pertama, aplikasi peta topografi ini mudah digunakan dengan materi yang cukup lengkap serta simulasi dengan menerapkan teknologi AR 
dan fitur 3D sehingga memudahkan dalam menggunakan dan mempelajari peta topografi. Kedua, aplikasi ini juga dapat memberikan interaksi kepada pengguna sehingga pengguna dapat lebih memahami materi yang disampaikan.

Beberapa saran yang dapat diberikan untuk pengembangan selanjutnya adalah sebagai berikut. Pertama, melakukan update terhadap materi dan simulasi apabila ada perubahan-perubahan untuk mendukung proses pembelajaran. Kedua, membuat tampilan 3D menjadi lebih halus supaya garis kontur lebih kelihatan dan mudah dipahami.

\section{DAFTAR PUSTAKA}

Azuma, R. T. (1997). Survey of Augmented reality. Diakses dari www.cs.unc.edu/ azuma/ARpresence.pdf.

Bentley, L. D., Dittman, K. C., Whitten, J. L. (2004). Systems Analysis Design Methods. (6th edition). New York: McGraw-Hill.

Ginting, P., Muhaimena, F. R., Pinem, S. (2007). IPS Geografi Jilid 3 untuk SMP Kelas IX. Jakarta: Erlangga. 